\title{
In Vitro Studies of Jatropha Curcas L. Latex Spray Formulation for Wound Healing Applications
}

\author{
Kittiya TINPUN ${ }^{1}$, Titpawan NAKPHENG ${ }^{1}$, Alwar Ramanujam PADMAVATHI ${ }^{1}$, Teerapol \\ SRICHANA ${ }^{1,2}$ \\ ${ }^{1}$ Drug Delivery System Excellence Center, Prince of Songkla University, Hat Yai, Songkhla- \\ 90112, Thailand. \\ ${ }^{2}$ Department of Pharmaceutical Technology, Faculty of Pharmaceutical Sciences, Prince of \\ Songkla University, Hat Yai, Songkhla- 90112, Thailand. \\ *Corresponding author :Teerapol Srichana, E-mail address :teerapol.s@psu.ac.th \\ Tel+ :66 74288979 .Fax+ :6674288979. \\ Department of Pharmaceutical Technology, Faculty of Pharmaceutical Sciences, Prince of \\ Songkla University, Hat Yai, Songkhla 90112, Thailand.
}

\begin{abstract}
Objective: There is an increasing demand for wound healing products of natural origin. Our objective is to develop a spray formulation from Jatropha curcas L. latex extracts for wound healing applications.
\end{abstract}

Materials and Methods: $J$. curcas L. latex was subjected to solvent extraction. The phytochemical structure was elucidated by ${ }^{1} \mathrm{H}-\mathrm{NMR}$ and confirmed by LC-MS spectrometry. A topical spray formulation prepared from $J$. curcas latex extracts were evaluated in antimicrobial activity and radical scavenging activity. The toxicity of formulation on fibroblast cell line, collagen production and wound healing activities were carried out.

Results: The ${ }^{1} \mathrm{H}-\mathrm{NMR}$ and mass spectrometric analyses revealed pure compound as curcacycline A. The $J$. curcas latex extract formulation had radical scavenging activity and antibacterial activities. Moreover, the formulation was not toxic to the human fibroblast cells while it stimulated collagen production and healed cell injury in $24 \mathrm{~h}$.

Conclusion: The $J$. curcas latex extract promoted the wound healing after cell injury. Our findings could rise the possibility of utilizing the $J$. curcas latex extract spray formulation as a potential the antibacterial, antioxidant and wound healing product from nature.

Key words: Jatropha curcas L. latex, Wound healing, Spray formulation, Collagen production, Antioxidant

Teerapol Srichana, Department of Pharmaceutical Technology, Faculty of Pharmaceutical

Sciences, Prince of Songkla University, Hat Yai, Songkhla- 90112, Thailand

teerapol.s@psu.ac.th

0000-0002-4772-2276

$66-74-28-6960$

08.11 .2018

14.02.2019

\section{INTRODUCTION}

wound is the effect of an injury that damages the dermis of the skin. It may vary from a simple, acute to chronic wound. Naturally, the human body possesses the potential to initiate wound healing to replace the damaged cellular structures and tissue layers. Wound healing is a complex process orchestrated by sequential events arising from homeostasis, inflammation, proliferation/granulation to remodelling/maturation. ${ }^{1}$ Wound care is a million-dollar industry and encompasses simple topical treatments to deep seated tissue regeneration using stem cell 
therapy. ${ }^{2}$ Wound care determines the appropriate treatment to promote wound healing with minimal infections. Despite of the medical advancements, there is a mounting demand for alternative treatments in the clinical and economic perspective to treat wounds. In ancient times, tribal healers used plant parts to cure wounds. Even now, plants are considered to be an enormous repertoire of novel bioactive agents. It has been determined that at present there are more than 450 plant species being exploited for their wound healing ability, ${ }^{3}$ yet, the search for novel wound healing agents from natural resources with minimal scar formation is incessant. With this milieu, Jatropha curcas L., a plant used for wound healing in folk medicine, was evaluated for its wound healing ability in vitro to substantiate its traditional use. In addition, the present study attempted to provide the Thai traditional knowledge by formulating the $J$. curcas extract as a spray suitable for modern day use. It has been used in folk medicine to treat burns, dermatitis, syphilis, inflammation, rash, rheumatism, scabies and sores, and its latex is known to possess wound healing activity. ${ }^{4,5}$ In addition to its enormous applications in folk medicine, it also demonstrated the natural binding ability of latex powder in tablets. ${ }^{6}$ Fagbenro-Beyioku and co-worker reported the anti-parasitic activity of $J$. curcas sap and proposed it as an effective malaria vector control agent. ${ }^{7}$ Preliminary evaluation of anti-HIV activity of $J$. curcas leaf extract was also reported. ${ }^{8} \mathrm{~J}$. curcas latex reduced the blood clotting time ${ }^{9}$ and in vitro studies of latex extracts have clearly demonstrated wound healing activity. ${ }^{10}$ Although $J$. curcas latex has been used in traditional wound healing, studies with mouse models have revealed that pure undiluted latex caused caustic lesions in mouse models. ${ }^{11}$ The sap was also found to be highly toxic to mice when administered orally or intraperitoneally. ${ }^{7}$ Against this backdrop, the present study aimed to evaluate bioactivity a spray formulation containing pure compound from J. curcas latex and evaluate the in vitro antimicrobial, antioxidant and wound healing potential.

\section{EXPERIMENTAL}

\section{Apparatus, cell lines, microbial and reagents}

The normal phase and reversed phase for thin layer chromatography paper and silica gel for column chromatography were purchased from Merck (Merck, Darmstadt, Germany). The $\mathrm{H}^{1}$ NMR spectrum was characterized by Varian FT-NMR spectrometer (Varian, Palo Alto, CA, USA). The molecular weight and fragmentation pattern of purified-samples were further analysed by ESI-Liquid Chromatograph Mass spectrometer (Micromass LCT, Altrincham, UK). The solvent content in the formulation after spraying was detected by Gas Chromatograph-Mass spectrometer (Trace GC Ultra, Thermo scientific, Inc., TX, USA) using AT-WasMS capillary column (30 mm x $0.25 \mathrm{~mm} ; 0.25 \mu \mathrm{m}$ film thickness). High performance liquid chromatography (HPLC, Waters, Milford, MA, USA) was used for investigated the physical stability of spray formulation. The scanning electron microscopy (SEM-Quanta; FEI Quanta 400, model: 1450 EP, Carl Zeiss Micro-Imaging, Inc., Thornwood, NY, USA) was used to obtain the information about morphology and film thickness of the spray formulation. The antibacterial activity was evaluated by gram positive bacteria including Staphylococcus aureus ATCC 25925 (S. aureus) and Staphylococcus epidermidis ATCC35983 (S. epidermidis) and gram negative bacteria including Escherichia coli ATCC 25922 (E. coli), Pseudomonas aeruginosa ATCC 27853 (P. aeruginosa) that were compared with clinical isolates of $S$. aureus, $S$. epidermidis, E. coli and $P$. aeruginosa (derived from clinical infections from Songkla Nagarind hospital, Hat Yai, Thailand). The bacteria were maintained in Brain Heart Infusion (BHI) broth (Becton, Dickinson and Company, NJ, USA). The cytotoxicity test was evaluated by a cell proliferation and viability assay using the the human keratinocyte cell line (HaCaT) (Cell Lines Service GmbH, Eppelheim, Germany) and the human fibroblast cell line (BJ) (ATCC, Manassas, VA, USA). 
Dulbecco's Modified Eagle Medium (DMEM), Eagle's Minimum Essential Medium (EMEM), fetal bovine serum (FBS), and antibiotics 1(penicillin-streptomycin were purchased from Gibco ${ }^{\circledR}\left(\right.$ Gibco $^{\circledR}$, Grand Island, NY, USA). The Sircol ${ }^{\circledR}$ collagen assay Kit was purchased from Biocolor Life Science Assays (Northern Ireland, Belfast, UK). The epidermal growth factor Proteoglycan IPC standard was bought from Ichimaru Pharcos (Ichimaru Pharcos Co. Ltd., Tokyo, Japan). The phase-contrast microscope (Olympus CK2, Tokyo, Japan) was used for photographed the monolayer of cells and analysed the distance between the scratches using an image processing program, image J1.42q (Fiji, Wisconsin, USA) and the distance between the scratches. All other reagents were of analytical grade and used without further purification.

\section{Collection of Jatropha Latex}

Jatropha curcas L. is a shrub belonging to a family Euphorbiaceae. It is originally native the tropical areas of the Americas from Mexico to Argentina, and has been spread throughout the world in tropical and subtropical regions. $J$. curcas is $2-5 \mathrm{~m}$ tall, produces a watery latex. ${ }^{12}$ In this work, the latex was collected from $J$. curcas (Specimen voucher number- SKP 071100301) plants that is available at the botanical garden maintained by the Department of Pharmaceutical Botany and Pharmacognosy, Prince of Songkla University, Hat Yai, Thailand. The latex was obtained by cutting the leaf stalk and the collected latex was immediately stored at $4^{\circ} \mathrm{C}$ until further use.

\section{Extraction, isolation and purification}

Latex $(100 \mathrm{~mL}, 107.8 \mathrm{~g})$ was diluted with $20 \mathrm{~mL}$ of distilled water and the mixture was extracted three times with $200 \mathrm{~mL}$ of $n$-hexane ( $200 \mathrm{~mL} \times 3$ replication). The solvent phase was separated and the aqueous phase was further extracted three times with $200 \mathrm{~mL}$ of ethyl acetate $(200 \mathrm{~mL} \times 3$ replication) followed by butanol $(200 \mathrm{~mL} \times 3$ replication). The remaining aqueous phase was allowed to dry and the other solvent extracts were evaporated using a rotary evaporator. All the test extracts were primarily isolated by TLC using normal and reverse phase pre-coated silica plates. The mobile phase was optimized using various solvents such as hexane, ethyl acetate, acetone, dichloromethane, chloroform, acetonitrile and methanol for the normal phase whereas different ratios of methanol and water were used to optimize the mobile phase for the reyerse phase TLC. The TLC plates were sprayed with $20 \% \mathrm{H}_{2} \mathrm{SO}_{4}$ and developed on a hot plate $\left(100{ }^{\circ} \mathrm{C}\right.$ for $\left.90 \mathrm{~s}\right)$. The solvent mixture that yielded better separation in TLC was used as a mobile phase for column chromatography using silica gel (230-400 mesh). Dried butanol extract ( $3 \mathrm{~g})$ was loaded on the silica column $(6 \times 32 \mathrm{~cm})$ and sequentially eluted with various ratios of chloroform: ethyl acetate: methanol $(7: 2: 1$, $6: 3: 1$ and $5: 4: 1)$. Fractions were collected, concentrated and tested for purity by TLC. Purified fractions were subjected to ${ }^{1} \mathrm{H}$ NMR in deuterated DMSO- $d_{7}$ and spectra was recorded at $500 \mathrm{MHz}$. The spectrum was processed using Vnmr software running with the Solaris operating system. The molecular weight and fragmentation patterns were analyzed by Electrospray ionization (ESI)-Liquid Chromatography Mass spectrometer (LC-MS). The ESI- LC-MS instrument was operated using electrospray ionization source (positive ion mode), with a source voltage at $4.0 \mathrm{kV}$, spray current at $100.0 \mu \mathrm{A}$, a desolvation temperature of $130^{\circ} \mathrm{C}$; source temperature: $120^{\circ} \mathrm{C}$; acquisition mode: scan $100-1500 \mathrm{~m} / \mathrm{z}$. Nitrogen gas was used for desolations and as tube lens gas.

\section{Preparation of spray formulation}

The $0.5 \%$ of $J$. Curcas latex extract (butanol extract) or curcacycline A was dissolved in ethanol and acetone as a co-solvent (80:20 v/v). One percentage of sorbitan monooleate $\left(\operatorname{Span}^{\circledR} 80\right)$ was used as a wetting and lubricating agent. The mixture was stirred overnight until a clear solution formed. The clear solution $(4 \mathrm{~g})$ was added to the spray canister and $8 \mathrm{~g}$ of hydrofluoroalkane propellant (HFA134a) was added to this and sealed. These formulations 
are henceforth addressed as $J$. curcas latex extract formulation $(\mathrm{JcF})$ and curcacycline A formulation (CAF).

\section{Stability tests}

The physical stability of JcF was observed for 3 months upon storage by monitoring the $\mathrm{pH}$, weight, colour change and appearance of the sediment. The curcacyclin A was resolved by high pressure liquid chromatography (HPLC) in a C18 reverse phase analytical column (150 $\times 4.6 \mathrm{~mm} ; 5 \mu \mathrm{m})$ using a methanol and water isocratic system $(50: 50)$. The sample $(15 \mu \mathrm{L})$ was automatically injected and elution was performed for $15 \mathrm{~min}$. The results were detected at the optimum wavelength of $\mathrm{OD}_{266} \mathrm{~nm}$. The $\mathrm{LC}$ was performed using the Waters Allianc 2690 liquid chromatography system $\mathrm{C}_{18}$ column $(2.1 \times 100 \mathrm{~mm} ; 3.5 \mu \mathrm{m})$.

\section{GC-MS analysis of spray formulation}

Gas Chromatography-Mass Spectrometer analysed (GC-MS) was employed to detect acetone in case left as a residue after spraying. The JcF was analysed by GC-MS to trace the solvent level of final product after application. JcF was sprayed 10 times in a glass beaker from a distance of $10 \mathrm{~cm}$ and briefly dried at ambient temperature. The dried content was reconstituted in acetonitrile and subjected to GC-MS analysis with an AT-WaxMS capillary column ( $30 \mathrm{~m} \times 0.25 \mathrm{~mm} ; 0.25 \mu \mathrm{m}$, film thickness) using the following conditions. Column oven temperature: Initial $50^{\circ} \mathrm{C}$, hold for $9 \mathrm{~min}$; Ramp to $120^{\circ} \mathrm{C}$ at $2^{\circ} \mathrm{C} \mathrm{min}-1$; Ramp to 200 ${ }^{\circ} \mathrm{C}$ at $25^{\circ} \mathrm{C} \mathrm{min}{ }^{-1}$, hold for $5 \mathrm{~min}$; Injection temperature: $150^{\circ} \mathrm{C}$; injection mode: splitless; sampling time: $1.00 \mathrm{~min}$; constant flow: $1 \mathrm{~mL}$ min-1; Ionization mode: Electron ionization; Acquisition mode: Scan, $30-500 \mathrm{amu}$; Ion source temperature: $230^{\circ} \mathrm{C}$. The chromatogram obtained was identified by comparison with the mass spectral database (NIST and WILEY Library, 2005).

\section{The scanning electron microscopy analysis}

The scanning electron microscopy (SEM-Quanta) was used to obtain the information on morphology and film thickness of the spray formulation. The spray formulation was sprayed on stubs, and coated with gold/palladium $(20 \mathrm{~nm})$. The specimens were viewed under a Zeiss EVO LS10 microscope using high-vacuum mode at $10 \mathrm{kV}$.

\section{Antioxidant activity}

The quantitative study of antioxidant activity was investigated. DPPH radical scavenging activity test, various concentrations $(7.75,15,31,62$ and $124 \mu \mathrm{g} / \mathrm{mL})$ of $J$. curcas latex extract, JcF or CAF were tested for their free radical scavenging activity using 2,2-diphenyl1-picrylhydrazyl (DPPH). ${ }^{13}$ Blank sample (ethanol: acetone (80: $\left.20 \mathrm{v} / \mathrm{v}\right), 1 \%$ sorbitan monooleate $\left.\operatorname{Span}^{\circledR} 80\right)$ was used as a negative control. The DPPH solution $(0.2 \mathrm{mM})$ was freshly prepared by dissolving $7.89 \mu \mathrm{g}$ of DPPH in $100 \mathrm{~mL}$ of methanol. Test extracts $(1 \mathrm{~mL})$ were mixed with $2 \mathrm{~mL}$ of DPPH solution and incubated in the dark for $30 \mathrm{~min}$. After incubation, the optical density (OD) was read at $517 \mathrm{~nm}$. The DPPH solution was mixed with $1 \mathrm{~mL}$ of DMSO that acted as a negative control and ascorbic acid as a positive control. The ntioxidant activity was calculated using the following formula:

$$
\text { Antioxidant activity }(\%)=\frac{\mathrm{OD}_{517} \text { of negative control }-\mathrm{OD}_{517} \text { of sample }}{\mathrm{OD}_{517} \text { of negative control }} \times 100
$$

\section{Antibacterial activity}

Antibacterial activity was performed using two strains of gram positive bacteria including $S$. aureus and $S$. epidermidis and gram negative bacteria including E. coli and $P$. aeruginosa. The bacteria were maintained in Brain Heart Infusion (BHI) broth at $37^{\circ} \mathrm{C}$ by the cylinder cup diffusion method and screened the clear zone of J. curcas latex extract, JcF and CAF. 
The stock solution of all extract was prepared at $500 \mathrm{mg} / \mathrm{mL}$, then loaded the extract solution to cylinder cup to obtain the final concentration of $10 \mathrm{mg} / \mathrm{cup}$. After incubation at $35^{\circ} \mathrm{C}$ for $24 \mathrm{~h}$, the presence of inhibition zones $(\mathrm{mm})$ were measured by Vernier calliper, recorded and considered as indication for antibacterial activity.

Broth microdilution was employed to obtain the Minimum inhibitory concentrations (MIC) and minimum bactericidal concentrations (MBC). The ATCC strains and clinical isolates strains of $S$. aureus, $S$. epidermidis, E. coli and $P$. aeruginosa were used in this assay. The assay was performed in 96-well polystyrene plates. Wells containing $100 \mu \mathrm{L}$ of BHI broth with formulation were inoculated with $10 \mu \mathrm{L}$ of bacterial suspension containing $10^{5}$ $\mathrm{CFU} / \mathrm{mL}$. The plate was incubated at $37^{\circ} \mathrm{C}$ for $18 \mathrm{~h}$. After incubation, $30 \mu \mathrm{L}$ of resazurin $(0.02 \% \mathrm{w} / \mathrm{v})$ was added to each well and further incubated for $5 \mathrm{~h}$. The MIC was determinec as the lowest concentration of test extract in which pink colouration was not observed. Vancomycin and gentamicin were used as positive controls. For the determination of the $\mathrm{MBC}$, the agar dilution method was employed. ${ }^{14}$ Blank sample (ethanol: acetone (80: 20 $\mathrm{v} / \mathrm{v}), 1 \%$ sorbitan monooleate $\operatorname{Span}^{\circledR} 80$ ) was used as a negative control.

\section{Evaluation of cytotoxicity}

The human keratinocyte cell line (HaCaT) and the human fibroblast cell line $(\mathrm{BJ})$ were maintained in Dulbecco's Modified Eagle Medium (DMEM)) and Eagle's Minimum Essential Medium (EMEM) respectively, supplemented with $10 \%$ fetal bovine serum (FBS) and antibiotics $\left(100 \mathrm{U}\right.$ penicillin and $100 \mathrm{U} / \mathrm{mL}$ streptomycin, at $37{ }^{\circ} \mathrm{C}$ with $5 \% \mathrm{CO}_{2}$. The cytotoxicity test was evaluated by a cell proliferation and viability assay using the $\mathrm{HaCaT}$ and BJ cell lines. ${ }^{15}$ The cells $\left(2 \times 10^{4}\right.$ cells $\left./ \mathrm{mL}\right)$ were seeded into the wells of a 96 wells plate with their respective medium. Various concentrations $(7.75,15,31,62$ and $124 \mu \mathrm{g} / \mathrm{mL})$ of $J$. curcas latex extract, JcF and CAF were added to the wells, and incubated at $37^{\circ} \mathrm{C}$ for $24 \mathrm{~h}$ with $5 \% \mathrm{CO}_{2}$. Cells without tested samples served as a control. In addition, blank sample (ethanol: acetone $(80: 20 \mathrm{v} / \mathrm{v}), 1 \%$ sorbitan monooleate $\left.\operatorname{Span}^{\circledR} 80\right)$ was used as a negative control. After incubation, the media were removed and the cells were rinsed with sterile phosphate buffered saline (PBS). The wells were supplemented with $100 \mu \mathrm{L}$ of fresh media and $10 \mu \mathrm{L}$ of 3-(4, 5-dimethylthiazol-2-yl)-2, 5-diphenyltetrazoliumbromide (MTT, 5 $\mathrm{mg} / \mathrm{mL}$ ) and incubated at $37^{\circ} \mathrm{C}$ for $4 \mathrm{~h}$. After incubation, the contents of the wells were removed and the formazan crystals formed were dissolved by adding $200 \mu \mathrm{L}$ of DMSO and measured at $540 \mathrm{~nm}$. The percentage of cell viability was calculated using the following formula:

$$
\text { Viability }(\%)=\frac{\text { Control } \mathrm{OD}_{540}-\text { Treated } \mathrm{OD}_{540}}{\text { Treated } \mathrm{OD}_{540}} \times 100
$$

\section{Estimation of the soluble collagen produced by human fibroblast cells}

Estimation of the soluble collagen produced by human fibroblast cells, the soluble collagen produced by BJ cell line was determined. ${ }^{16} \mathrm{BJ}$ cells were seeded into the wells of a 96 wells plate at an initial concentration of $2 \times 10^{4}$ cells $/ \mathrm{mL}$ in EMEM supplemented with $10 \%$ FBS. Various concentrations $(7.75,15,31,62$ and $124 \mu \mathrm{g} / \mathrm{mL})$ of extracts $J$. curcas latex extract, $\mathrm{JcF}$ and CAF were added to the cells and incubated at $37^{\circ} \mathrm{C}$ for $24 \mathrm{~h}$ in a $5 \% \mathrm{CO}_{2}$ atmosphere. Proteoglycan IPC was extracted from nasal cartilage of Oncorhynus keta (Saimon) having property like epidermal growth factor. It was used as a positive control. BJ cells alone served as a control. After incubation, $100 \mu \mathrm{L}$ of supernatants were collected separately and the total soluble collagen (type I) was quantified using $1 \mathrm{~mL}$ of a Sircol ${ }^{\circledR}$ collagen assay Kit. The mixture was incubated at room temperature for $30 \mathrm{~min}$ and then subjected to centrifugation at $15,000 \mathrm{rpm}$ for $10 \mathrm{~min}$. The collagen was obtained as a pellet and dissolved in $1 \mathrm{~mL}$ of an alkaline reagent $(0.5 \mathrm{M} \mathrm{NaOH})$. The solution was transferred to a 
96 wells plate and the optical density was measured at $540 \mathrm{~nm}$. A standard curve was prepared using standard bovine skin collagen type I obtained from American disease free animals. The soluble collagen produced by BJ cells in the presence and absence of JcF was calculated based on the standard curve. Blank sample (ethanol: acetone (80:20 v/v), $1 \%$ sorbitan monooleate $\operatorname{Span}^{\circledR} 80$ ) was used as a negative control.

\section{Assay for the cell culture wound closure}

In vitro wound closure assay, the wound closure assay in cultured cells was done to assess the in vitro wound healing ability of $\mathrm{JcF}$ in the HaCat and $\mathrm{BJ}$ cell lines. ${ }^{16}$ The wells of a 6 wells plate were seeded with $5 \times 10^{4}$ cells $/ \mathrm{mL}$ with appropriate culture medium and allowed to grow as a confluent monolayer. A linear scratch was then created using a sterile tip and the wells were washed with sterile PBS to remove cell debris. Culture medium $(2 \mathrm{~mL})$ was added to the wells along with (treated, $31 \mu \mathrm{g} / \mathrm{mL}$ ) and without JcF (blank sample) was used as a negative control. This was considered as Day 0 and photographs of the monolayer were acquired at $100 \mathrm{X}$ magnification using a phase-contrast microscope. The plates were incubated at $37^{\circ} \mathrm{C}$ for $24 \mathrm{~h}$ in a $5 \% \mathrm{CO}_{2}$ atmosphere. After incubation, the celis were again photographed at Day 1 . These images were examined using an image processing program and the distance between the scratches were measured and the cell migration rate was calculated using the following formula:

Migration rate $(\%)=\frac{\text { Distance between scratch }(\text { day } 0)-\text { Distance between day } 1}{\text { Distance between at day } 0} \times 100$

\section{Statistics}

Assays were performed in triplicate and the values were expressed as mean \pm S.D. One-way analysis of variance (ANOVA) was carried out using the SPSS version 17.0. The significance was set at $\mathrm{p} \leq 0.05$.

\section{RESULTS}

\section{Extraction, isolation and purification}

Solvent extraction (hexane, ethyl acetate, butanol and water extracts) of the $J$. curcas latex (107.8 g) yielded a total of $10.81 \mathrm{~g}$ that comprised the extracts from hexane (5 g; $19 \%)$, ethyl acetate $(5 \mathrm{~g} ; 19 \%)$ butanol $(4.81 \mathrm{~g} ; 30 \%)$ and water $(5.36 \mathrm{~g} ; 33 \%)$. All the test extracts were subjected to TLC using normal and reverse phase pre-coated silica plates and found that hexane, ethyl acetate, butanol and water fractions have a similar TLC profile (data not shown), but a few additional bands were observed in the butanol fraction. Thus, butanol fraction was chosen for further purification with the silica gel open column chromatography. Hence, the butanol fraction ( $3 \mathrm{~g}$ ) were subjected to further fractionation by open column chromatography. Among the 200 fractions collection, we found that fractions 9 and 10 yielded a single abundant band in the TLC with a retention factor $\left(R_{f}\right)$ of 0.29 . Then, the pure compound from fractions 9 and 10 were further identified by ${ }^{1} \mathrm{H}-\mathrm{NMR}$ and found to be curcacycline A (pure compound) which is a major constituent of $J$. curcas latex (Table 1). Curcacycline A compound was further confirmed by mass spectrometric analysis corresponding to $\mathrm{C}_{37} \mathrm{H}_{67} \mathrm{~N}_{8} \mathrm{O}_{9}{ }^{+} \mathrm{Na}^{+}$(Fig. 1).

\section{Spray formulation}

$J$. curcas latex spray formulation (JcF) was prepared from butanol extract fraction employing various compositions (Table 2) and it was found that the formulation with $J$. curcas extract $(0.5 \%)$, ethanol $(78.5 \%)$, acetone $(20 \%)$ and span $80(1 \%)$ had preserved its bioactivity. JcF ( $\mathrm{pH}:$ 7) exhibited a clear solution (Fig. 2). In addition, curcarcycline A formulation (CAF) was also prepared as the same conditions with JcF and revealed that the formulation with curcarcycline A $(0.5 \%)$, ethanol (78.5\%), acetone $(20 \%)$ and span $80(1 \%)$ showed a clear solution without precipitation (data not shown). We collected these both formulation to further investigation on bioactivity.

\section{Chemical and physical stability tests}


Storage did not affect the stability, $\mathrm{pH}$, weight, colour and homogeneity of JcF. HPLC analysis of $\mathrm{JcF}$ revealed a major peak eluted at $1.98 \mathrm{~min}$ with $81 \%$ recovery. LC-MS analysis and ESI-MS spectra fragmentation pattern revealed the major constituent as curcacycline A. From the GC-MS analysis revealed the presence of $7.4 \%$ of ethanol (data not shown) and acetone residue was not detected due to a quick evaporation. The 10000x of micrographs of the spray formulation from SEM are shown in Fig. 3. The Figure 3A displayed the film on the stub that the film intersperse droplets and small particles were observed on a surface. Furthermore, a cross section SEM revealed that the formulation formed a thin film after spraying on the stub (Fig. 3B). Furthermore, curcacycline A was used to formulate the CA using the same excipient, which revealed the similar physical properties to JcF (data not shown).

\section{The antioxidant activity and antibacterial activity}

The antioxidant activity of $J$. curcas latex extract, JcF and CAF are illustrated in Fig. 4. Th results showed that $J$. curcas latex extract and JcF significantly increased antioxidant in a concentration dependent manner, but not for CAF. In addition, the inhibition zone of antimicrobial activity is in Table 3 . The results revealed that both $J$. curcas latex extract and $\mathrm{JcF}$ possessed antibacterial activity with MIC and $\mathrm{MBC}$ at $5 \mathrm{mg} / \mathrm{mL}$ against both gram negative and gram positive bacteria and their clinical isolates, whereas vancomycin and gentamicin exhibited MIC at 1 and $4 \mu \mathrm{g} / \mathrm{mL}$ against gram positive and gram negative bacteria, respectively. Notably, the inhibition zone of antimicrobial activity of CAF was not observed against both types of bacterial.

\section{The cytotoxicity}

The cytotoxicity of $J$. curcas latex extract, JcF and CAF in HaCat and BJ cell was evaluated using MTT assay. The result revealed that cell viability of HaCat cell presented higher than $80 \%$ at all concentrations of all tested samples (Fig. 5A). However, the concentration at 62 and $124 \mu \mathrm{g} / \mathrm{mL}$ of $J$. curcas latex extract significantly decreased cell viability of BJ cell while JcF- and CAF-treated BJ cells was not toxic (>80\%) (Fig. 5B). Notably, JcF- and CAFtreated $\mathrm{HaCat}$ and $\mathrm{BJ}$ cells displayed more than $80 \%$ of cell viability at all concentrations (Fig. 5).

\section{The collagen production and wound he aling}

The collagen production after treated with $J$. curcas latex extract, JcF and CAF in human fibroblast BJ cells was determined using Sircol assay. The results showed that $J$. curcas latex extract and $\mathrm{JcF}$ promoted the collagen production in BJ cell in a concentration dependant manner, whereas collagen production was not observed in CAF-treated cells (Fig. 6). In fact, $J$. curcas latex extract lightly promoted the collagen production $(47-198 \mathrm{pg} / \mathrm{mL})$, while JcF prominently promoted the collagen production $(179-335 \mathrm{pg} / \mathrm{mL})$. The results from above revealed that JcF exhibited the good collagen production activity and non-toxic to both cells, but not for $J$. curcas latex extract or CAF. Thus, we selected the JcF for further investigated the wound healing activity. The wound healing in HaCat and $\mathrm{BJ}$ cells was also determined using scratch assay, the proteoglycan IPC $(1 \mu \mathrm{g} / \mathrm{mL})$ was used as a positive control. In this study, we used the concentration at $31 \mu \mathrm{g} / \mathrm{mL}$ of JcF for wound healing. The results after treated for $24 \mathrm{~h}$ showed that JcF completely promote the wound healing in HaCat and BJ cells (Fig. 7A and B). Indeed, the wound healing of JcF-treated HaCat cell was more rapidly than proteoglycan IPC (positive control), but similar in BJ cells.

\section{DISCUSSION}

The structure elucidation of pure compound from $J$. curcas latex extracts, the ${ }^{1} \mathrm{H}-\mathrm{NMR}$ revealed eight position of the chemical shifts at 8.52, 8.46, 8.32, 8.16, 8.04, 7.80 and 7.59 ppm (Table 1). This characteristic of ${ }^{1} \mathrm{H}-\mathrm{NMR}$ indicates the protons of amino acid residues, a cyclic octa-peptide, on curcacycline A which has been reported in various parts of $J$. 
Curcas. ${ }^{17}$ In addition, The ESI-MS was displayed $789.5 \mathrm{~m} / \mathrm{z}$ corresponding to $\mathrm{C}_{37} \mathrm{H}_{67} \mathrm{~N}_{8} \mathrm{O}_{9}{ }^{+} \mathrm{Na}^{+}$that similarity search with the mass spectral database revealed the closed match as curcacycline A. ${ }^{18}$ The data from ${ }^{1} \mathrm{H}-\mathrm{NMR}$ and ESI-MS supported together that pure compound is a curcacycline A.

Next, J. curcas latex extract and curcacycline A was used to formulate the JcF and CAF using ethanol, acetone, Span 80 and propellants as an excipient. The results revealed that formulations retained in the properties including, $\mathrm{pH}$, weight, colour and homogeneity of the formulation, suggesting this formulation was stable at room temperature. In addition, LC-MS analysis of the $\mathrm{JcF}$ revealed that curcacycline A was stable in this formulation. Furthermore, The GC-MS results detected a low amount of ethanol residue due to a quick evaporation. The concentration of ethanol in $\mathrm{JcF}$ is also less than that of typical antiseptic alcohol which contains $>70 \%$ ethanol. The absence of acetone guaranteed the safety of JcF towards wound. In addition, the film thickness of JcF from SEM data suggested that the spray formulation formed a uniform film containing some particles on a film surface. Moreover, a cross section SEM showed that the JcF formed a thin layer of film after spraying on to a stub with a thickness of 1-2 $\mu \mathrm{m}$. For CAF, the physical and chemical properties of this formulation was similarly observed to JcF.

In the biological activity's studies, J. curcas latex extract and JcF had high antioxidant potency, but not for CAF. A similar phenomenon was observed for antimicrobial activity in the microbial tests on gram positive and negative that J. curcas latex extract and JcF showed significant antimicrobial activities, but not for CAF. These suggested that a curcacycline A is not an active compound for those biological activity. Most antioxidants are likely to promote wound healing. ${ }^{19}$ The $J$. curcas extract illustrated its potential to possess antimicrobial and antioxidant activities. Thus, the JcF with antioxidant activity could promote wound healing while preventing reactive oxygen species (ROS) mediated further cellular damage at the wounded site. Most of the wound infections are colonized by polymicrobial infections consisting of both gram positive and gram negative bacteria but many classes of antibiotics are effective against either gram positive or negative bacteria. Though broad spectrum antibiotics can be administered to control the wound infections, this could cause an increase in the incidence of antibiotic resistance in clinical use. ${ }^{20}$ In addition, there will be a requirement for the administration of wound healing products. The ability of $J$. curcas extract to control both gram positive and gram negative bacteria and its wound healing potential assures its perpetual applications in wound care products. The ability of $J$.curcas latex ointments in controlling pathogens was also proven which goes well with the present study. ${ }^{21,22}$

In vitro cytotoxic study of $J$. curcas latex extract, JcF and CAF in human keratinocyte cell line and human fibroblast cell line were investigated. All concentrations of JcF and CAF were not toxic and stimulate cell growth in both cells, but not for J. curcas latex extract in BJ cells, suggesting that the JcF and CAF is safer than J. curcas latex crude extract.

Furthermore, JcF increased the collagen production and will have a positive impact on improving the wound healing, but not for CAF. This suggested that a curcacycline A is not an active compound for collagen production. Collagen has been known to play a major role in wound healing and re-epithelialization which is crucial for wound closure. It acts as a reinforcing factor by increasing the strength of the wound that helps to restore the functionality of the skin. ${ }^{1}$ Previous studies with $J$. curcas latex revealed its toxicity towards fibroblasts. ${ }^{23}$ However, in our studies JcF is likely to promote wound healing potential without inducing any toxicity to fibroblast cells. In the scratch assay, 'expanding' mode of human keratinocytes was enhanced in the presence of $\mathrm{JcF}$ and the results were significantly better than the positive control of proteoglycan IPC, suggesting the potentially high wound 
healing property. This expanding mode may activate the wound closure and switch back to a 'balanced' mode that will maintain homeostasis. ${ }^{24} \mathrm{JcF}$ reduced the time required for wound re-epithelialization that also hastened the wound healing process which is already evident from the studies carried out with the $J$. curcas plant exudates, ${ }^{25}$ leaf extract ${ }^{26}$ and ointment prepared from it. ${ }^{27}$ The ointment prepared from $J$. curcas was proven to be safe for albino rats as histopathology of liver and kidney were found to be unaltered. ${ }^{28}$ The rate of reepithelialization is important to avoid scarring which is considered as a social stigma. The efficiency of spray formulation in increasing the natural healing process will aid in development of better wound care product. Wound healing is a complex process orchestrated by various cellular events from cell migration and proliferation to remodelling. Several studies have shown that the accumulation of oxidative stress hampers the healing process and advised the usage of locally applied antioxidants to reduce hypoxia and to promote wound healing. ${ }^{29,30}$ Previous study has revealed the active ingredient responsible for wound healin as curcain. ${ }^{31,32}$ However, in our study we cannot detect curcain in the extraction process.

\section{CONCLUSION}

The present study, for the first time reports the formulation of a spray from $J$. curcas latex extract with potential applications in would healing, but not for the formulation of a spray from curcacycline A. The study also found that the latex extract formulation preserved the bioactive potentials such as antimicrobial, antioxidant and wound healing without any lost in function. Development of a spray product for treating wounds had advantages over other formulations like ointment or creams that alter the healing process. The ability to induce collagen, prevent microbial infections and antioxidant property of the JcF greatly enhances its wound healing potentials.

\section{ACKNOWLEDGEMENTS}

The authors acknowledge the financial assistance provided by Prince of Songkla University (Grant no. PHA570862S). Instrumentation facility provided by Drug delivery system excellence center, Faculty of Pharmaceutical sciences is also thankfully acknowledged. Thanks to Dr. Brian Hodgson for assistance with the English.

\section{CONFLICT OF INTEREST}

The authors declare there is no conflict of interest.

\section{REFERENCES}

1. Kirsner RS, Eaglstein WH. The wound healing processes. Dermatol. Clin. 1993; 11: 629-640.

2. Hu MS, Leavitt T, Malhotra S, Duscher D, Pollhammer MS, Walmsley GG, Maan ZN, Cheung ATM, Schmidt M, Huemer GM, Longaker MT, Lorenz HP. Stem cell-based therapeutics to improve wound healing. Plast. Surg. Int. 2015; 1-7.

3. Ghosh PK, Gaba A. 2013. Phyto-extracts in wound healing. J Pharm Pharm Sci. 2015; 16(5): $760-820$.

Watt JM, Breyer-Brandwijk MG. The medicinal and poisonous plants of southern and eastern Africa: being an account of their medicinal and other uses, chemical composition, pharmacological effects and toxicology in man and animal. E. \& S. Livingstone. 1962; 19621457.

5. Balqis U, Darmawi, Iskandar CD, Salim MN. Angiogenesis activity of Jatropha curcas L. latex in cream formulation on wound healing in mice. Vet World. 2018; 11(7): 939943. 
6. Ghatage S, Patil S, Patrakar R, Patil S. Formulation and Evaluation of Tablet using Latex Powder of Jatropha curcas as a Natural Binder. J. Appl. Pharm. Sci. 2015; 5(01), 077081.

7. Fagbenro-Beyioku AF, Oyibo WA, Anuforom BC. Disinfectant/antiparasitic activities of Jatropha curcas. East Afr. Med. J. 1998; 75: 508-511.

8. Dahake R. Potential anti-HIV activity of Jatropha curcas Linn. leaf extracts. J. Antivir. Antiretrovir. 2013; 5: 160-165.

9. Osoniyi O, Onajobi F. Coagulant and anticoagulant activities in Jatropha curcas latex J. Ethnopharmacol. 2003; 89: 101-105.

10. Villegas LF, Fernandez ID, Maldonado H, Torres R, Zavaleta A, Vaisberg AJ, Hammond GB. Evaluation of the wound-healing activity of selected traditional medicinal plants from Perú. J. Ethnopharmacol. 1997; 55: 193-200.

11. Salas J, Tello V, Zavaleta A, Villegas L, Salas M, Fernández I, Vaisberg A [Cicatrization effect of Jatropha curcas latex (Angiospermae: Euforbiaceae)]. Rev. Biol Trop. 1994; 42: 323-326.

12. Heller J. Physic nut, Jatropha curcas L. ( $1^{\text {st }}$ edition). Rome. IP GRI. 1996; $1-66$. 13. Balekar N, Katkam NG, Nakpheng T, Jehtae K, Srichana T. Evaluation of the wound healing potential of Wedelia trilobata (L.) leaves. J. Ethnopharmacol. 2012; 141: 817-824.

14. Mostafa AA, Al-Askar AA, Almaary KS, Dawoud TM, Sholkamy EN, Bakric MM. Antimicrobial activity of some plant extracts against bacterial strains causing food poisoning diseases. Saudi J Biol Sci. 2018; 25(2): 361-366.

15. Balekar N, Nakpheng T, Katkam NG, Srichana T. Wound healing activity of entkaura-9(11), 16-dien-19-oic acid isolated from Wedelia tyilobata (L.) leaves. Phytomedicine. 2012; 19: 1178-1184.

16. Aramwit P, Kanokpanont S, De-Eknamkul W, Kamei K, Srichana T. The effect of sericin with variable amino-acid content from different silk strains on the production of collagen and nitric oxide. J. Biomater. Sci. Polym. Ed. 2009; 20: 1295-1306.

17. Van den Berg AJ, Horsten SF, Kettenes-van den Bosch JJ, Kroes BH, Beukelman CJ, Leeflang BR, Labadie RP. Curcacycline A--a novel cyclic octapeptide isolated from the latex of Jatropha curcas L. FEBS Lett. 1995; 358: 215-218.

18. Insanu M, Anggadiredja J. Curcacycline A and B - new pharmacological insights to an old drug. Int J Appl Res Nat Prod. 2012; 5 (2): 26-34.

19. Kefayati Z, Motamed SM, Shojaii A, Noori M, Ghods R. Antioxidant activity and phenolic and flavonoid contents of the extract and subfractions of euphorbia Splendida Mobayen. Pharmacognosy Res. 2017; 9(4): 362-365.

20. Dohmen PM. Antibiotic resistance in common pathogens reinforces the need to minimise surgical site infections. J. Hosp. Infect. 2008; 70: 15-20.

21. Oyi RA, Onaolapo JA, Haruna KA. Evaluation of Jatropha curcas latex ointment formulations in-vitro and in-vivo. J. Pharm. Bioresour. 2005; 2: 5-12.

22. Arekemase MO, Kayode RMO, Ajiboye AE. Antimicrobial activity and

phytochemical analysis of Jatropha Curcas plant against some selected microorganisms. Int. J. Biol., 2011; 3: 52-59.

23. Siregar F, Akbar SMS. Cytotoxicity of Jatropha curcas (Euphorbiaceae) latex on fibroblast by MTT assay. Med. J. Indones. 2000; 23(3): 143-148.

24. Roshan A, Murai K, Fowler J, Simons BD, Nikolaidou-Neokosmidou V, Jones PH. Human keratinocytes have two interconvertible modes of proliferation. Nat. Cell Biol. 2016; 18: $145-156$.

25. Ligha A, Fawehimi H. Histopathological observations of the wound healing properties of plant exudates of Jatropha curcas Linn. J. Exp. Clin. Anat. 2009; 7(1): 17-21. 
26. Odoh U, Ezugwe C, Menkiti C, Ezejiofo M. Chromotographic and wound healing studies of Jatropha curcas (Euphorbiacea). J Pharm Allied Sci. 2011; 7: 2.

27. Esimone CO, Nworu CS, Jackson CL. Cutaneous wound healing activity of a herbal ointment containing the leaf extract of Jatropha curcas L. (Euphorbiaceae). Int J App Res Nat Prod. 2008; 14: 1-4.

28. Akaninwor JO, Omeni C, Monanu MO. Use of extracts of Jatropha Curcas leaf formulated in a simple ointment base in wound healing activities: how safe is it? Inter. IJESI. 2013; 53-57.

29. Sen CK, Khanna S, Gordillo G, Bagchi D, Bagchi M, Roy S. Oxygen, oxidants, an antioxidants in wound healing: an emerging paradigm. Ann. N. Y. Acad. Sci. 2002; 957: 239-249.

30. Fitzmaurice SD, Sivamani RK, Isseroff RR. Antioxidant therapies for wound healing: A clinical guide to currently commercially available products. Skin Pharmacol. Physiol. 2011; 24: 113-126.

31. Nath LK, Dutta SK. Extraction and purification of curcain, a protease from the latex of Jatropha curcas Linn. J. Pharm. Pharmacol. 1991; 43: 111-114.

32. Nath LK, Dutta SK. Wound healing responses of the proteolytic enzyme curcain. Indian J. Pharmacol. 1992; 24: 114-115.

Table 1 Comparison of ${ }^{1} \mathrm{H}-\mathrm{NMR}$ of pure compound with reported curcacycline A. ${ }^{17}$

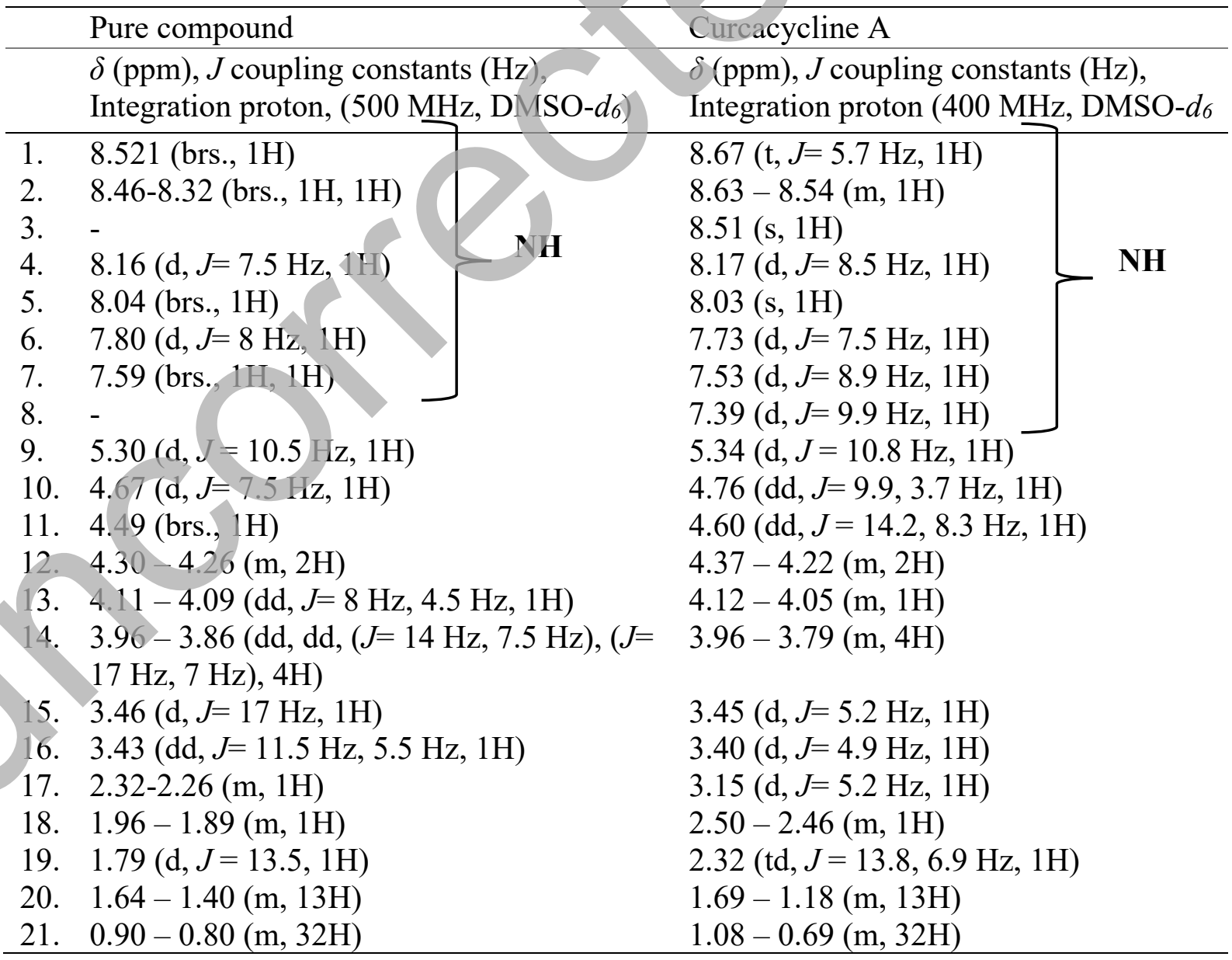


*s: singlet, d: doublet, dd: doublet of doublet, m: multiplet, brs: broad singlet

Table 2 J. curcas extract spray formulation design.

\begin{tabular}{|c|c|c|c|c|c|c|c|c|c|}
\hline \multirow[t]{2}{*}{ Ingredients } & \multicolumn{8}{|c|}{ Compositions \% (w/w) } & \multirow[b]{2}{*}{$\mathrm{F} 9$} \\
\hline & F1 & $\mathrm{F} 2$ & F3 & $\mathrm{F} 4$ & F5 & F6 & F7 & F8 & \\
\hline J. curcas extract & 0.5 & 0.5 & 0.5 & 0.5 & 0.5 & 0.5 & 0.5 & 0.5 & 0.5 \\
\hline Ethanol & 78.5 & 78.5 & 77.5 & 75.5 & 76.9 & 78 & 76.5 & 75.4 & 78.5 \\
\hline Acetone & 20 & 20 & 20 & 20 & 20 & 20 & 20 & 20 & 20 \\
\hline PEG 400 & - & 0.5 & 1 & 2 & 0.5 & 0.5 & 1 & 2 & - \\
\hline Span 80 & 1 & 0.5 & 0.2 & 1 & 0.5 & 0.1 & 1 & 0.5 & - \\
\hline Eudragit ${ }^{\circledR}$ E100 & - & 0.1 & 0.5 & 1 & 0.1 & 0.5 & 1 & 0.1 & 0.5 \\
\hline Kollidon ${ }^{\circledR}$ VA 64 & - & 0.1 & 0.5 & 1 & 0 & 0.5 & 1 & 0.1 & 0.5 \\
\hline Kolliphor P & - & 1 & 0.5 & 0 & & 0.5 & 0.2 & 1 & 0.5 \\
\hline Test results & $\checkmark$ & $\mathrm{x}$ & $\mathrm{X}$ & $\mathrm{x}$ & & $\mathrm{x}$ & $\mathrm{x}$ & $\mathrm{X}$ & $\mathrm{x}$ \\
\hline
\end{tabular}

$\checkmark-$ No precipitation, $\mathrm{x}$ - Precipitation

Table 3 Antibacterial activity of $J$. curcas extract and JcF against reference and clinical isolates of gram positive and negative bacteria. Notably, antibacterial activity of CAF did not show in this table due to cannot measured their inhibition zone.

\begin{tabular}{llll}
\hline Pathogen & Strain & \multicolumn{2}{l}{ Zone of inhibition (mm) } \\
\cline { 3 - 4 } & & J. curcas latex extract & $\mathrm{JcF}$ \\
\hline S.aureus & ATCC25925 & $23 \pm 0.2$ & $25 \pm 0.5$ \\
& Clinical isolate & $15 \pm 0.3$ & $14 \pm 0.5$ \\
\hline S.epidermidis & ATCC35983 & $23 \pm 0.2$ & $27 \pm 0.2$ \\
& Clinical isolate & $20 \pm 0.2$ & $20 \pm 0.1$ \\
\hline E.coli & ATCC25922 & $23 \pm 0.2$ & $21 \pm 0.1$
\end{tabular}




\begin{tabular}{llll} 
& Clinical isolate & $12 \pm 0.5$ & $12 \pm 0.2$ \\
\hline P.aeruginosa & ATCC27853 & $22 \pm 0.1$ & $20 \pm 0.2$ \\
& Clinical isolate & $14 \pm 0.1$ & $12 \pm 0.2$ \\
\hline
\end{tabular}

\section{Figure legends}

Figure 1. The molecular structure of curcacycline A.

Figure 2. Formulation of $J$. curcas latex extract filled in metered dose spray canister.

Figure 3. The surface morphology of JcF spray droplets (A) and thin film micrographs of JcF

(B).

Figure 4. Antioxidant activity of $J$. curcas latex extract, JcF and CAF. Various concentration of tested samples were tested for their free ridical scavenging activity using 2,2-diphenyl-1picrylhydrazyl (DPPH). Blank sample (ethanol: acetone $(80: 20 \mathrm{v} / \mathrm{v}), 1 \%$ sorbitan monooleate Span ${ }^{\circledR} 80$ ) was used as a negative control.

Figure 5. Cytotoxicity evaluation of $J$. curcas latex extract, JcF and CAF using HaCaT cells (A) and BJ cells (B). Blank sample (ethanol: acetone (80:20 v/v),1\% sorbitan monooleate Span ${ }^{\circledR} 80$ ) was used as a negative control.

Figure 6. Collagen production by BJ cells treated with various concentrations of $J$. curcas latex extract, JcF and CAF. Blank sample (ethanol: acetone $(80: 20 \mathrm{v} / \mathrm{v}), 1 \%$ sorbitan monooleate $\operatorname{Span}^{\circledR} 80$ ) was used as a negative control.

Figure 7. (A) In vitro wound closure assay of BJ cells with (JcF \& Proteoglycan IPC) and without (negative control) treatment. (B) In vitro wound closure assay of $\mathrm{HaCaT}$ cells with (JcF \& Proteoglycan IPC) and without (negative control) treatment. Scale bar indicates 100 microns. 


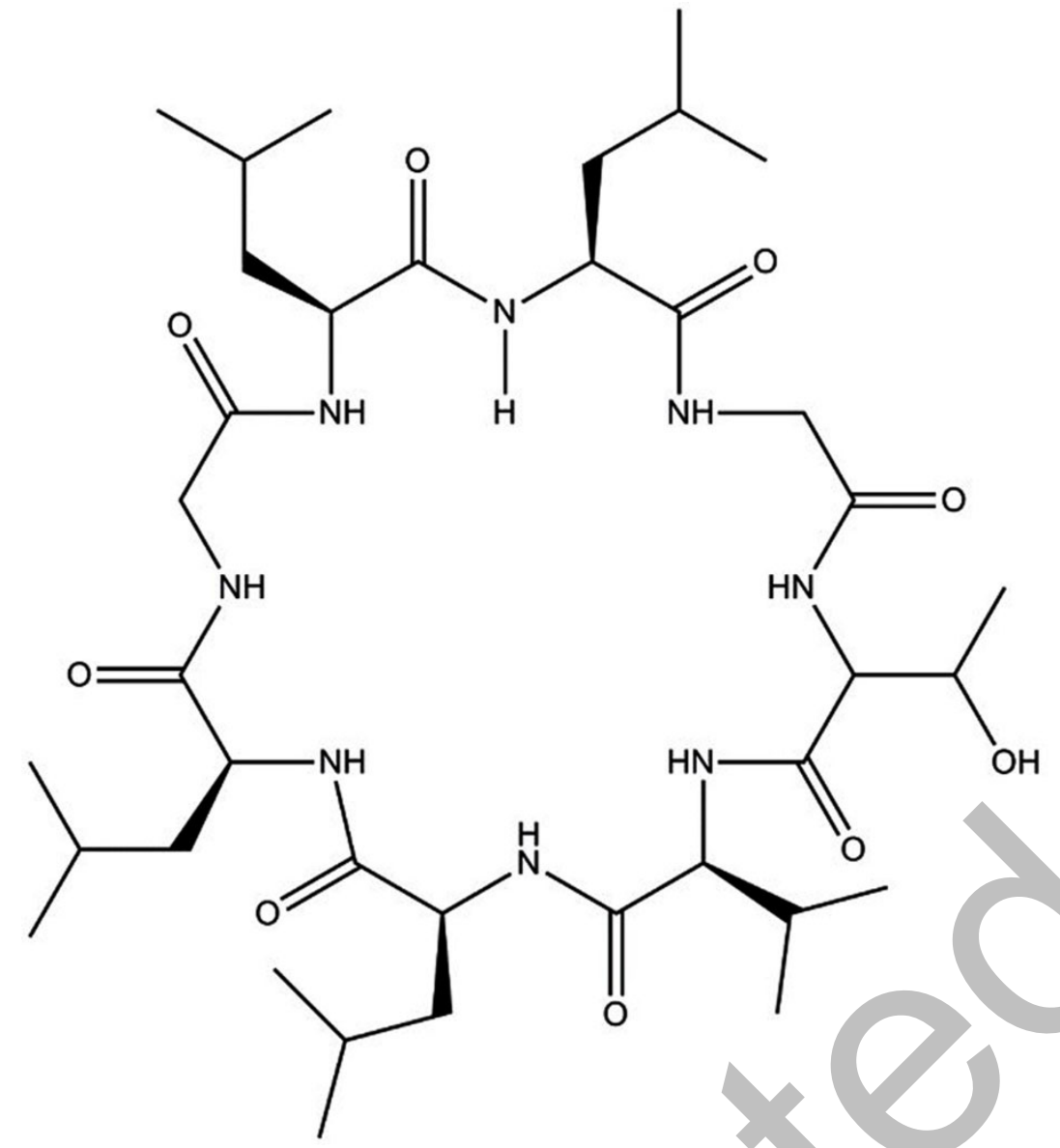

Figure 1 


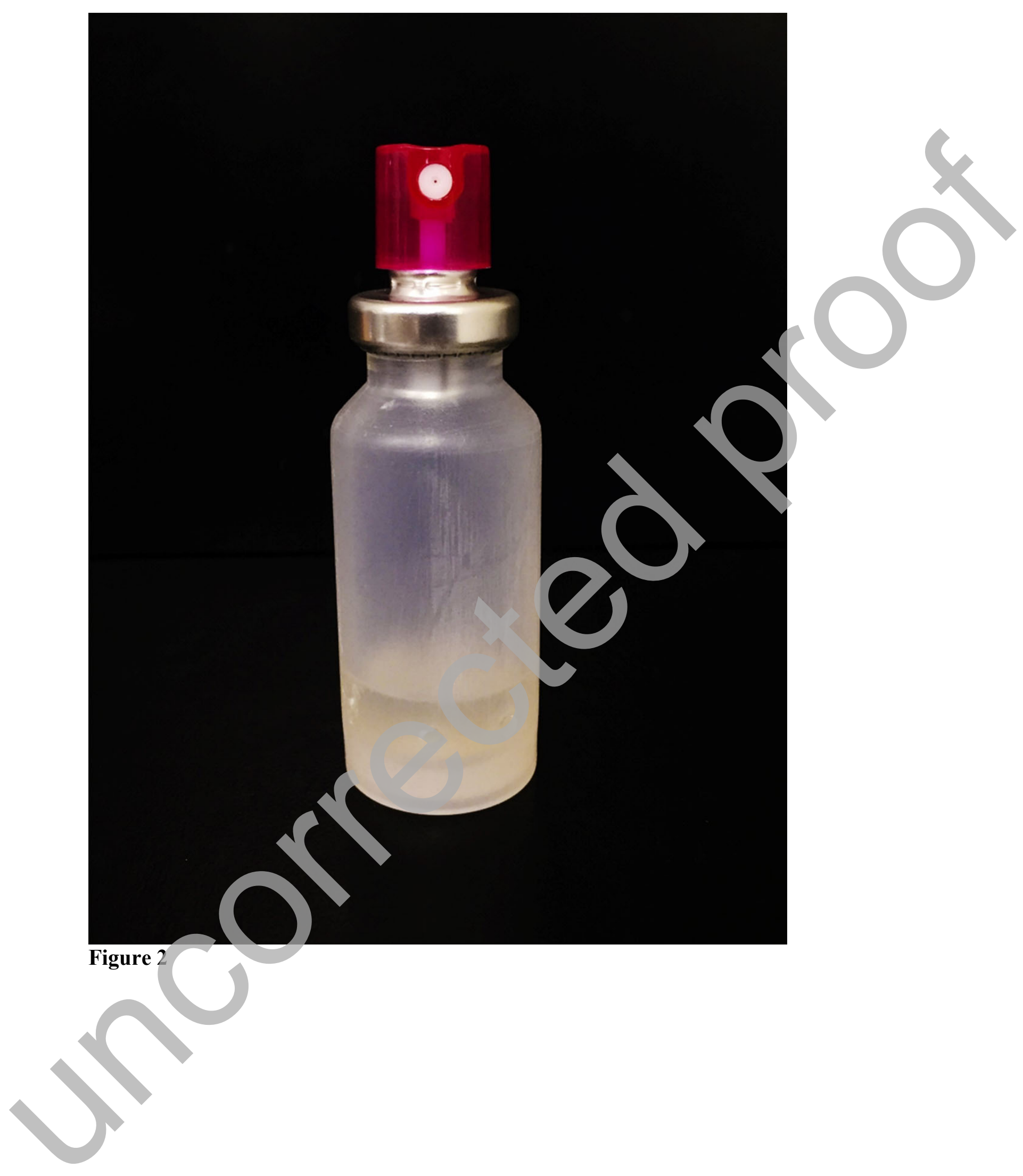




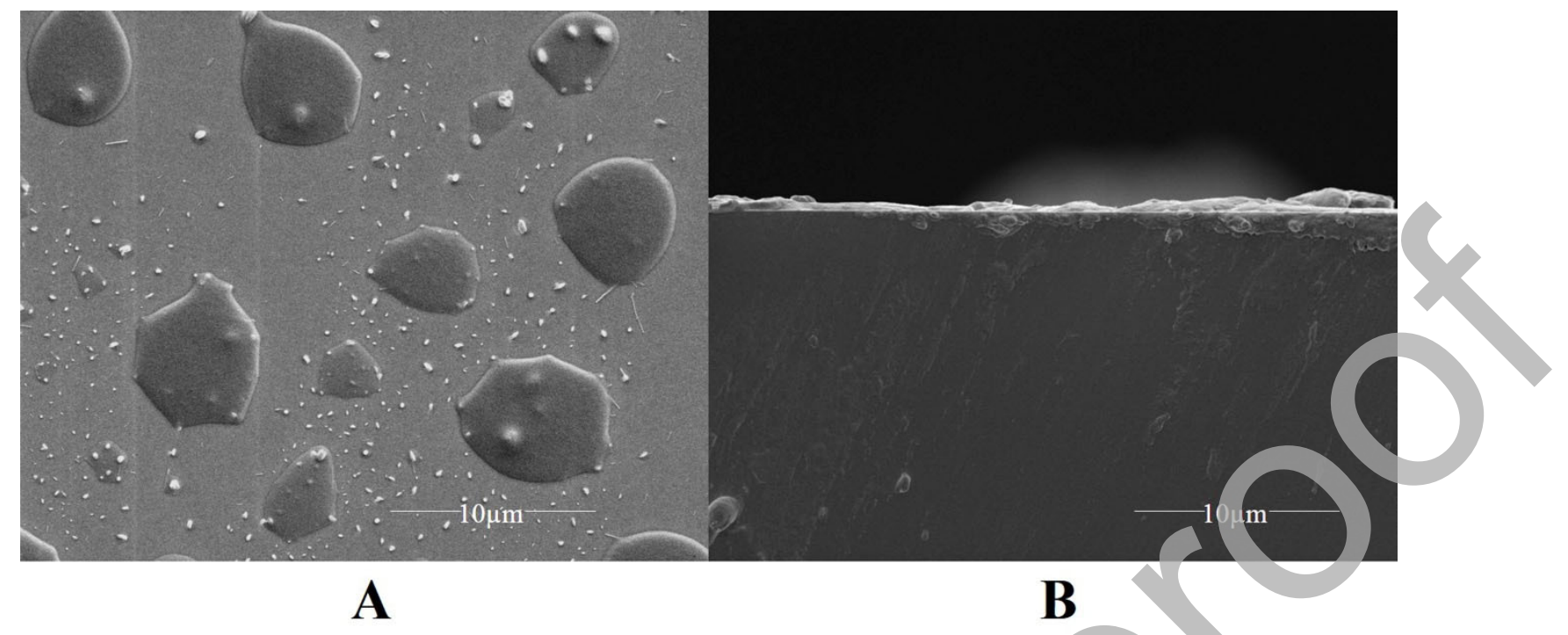

Figure 3

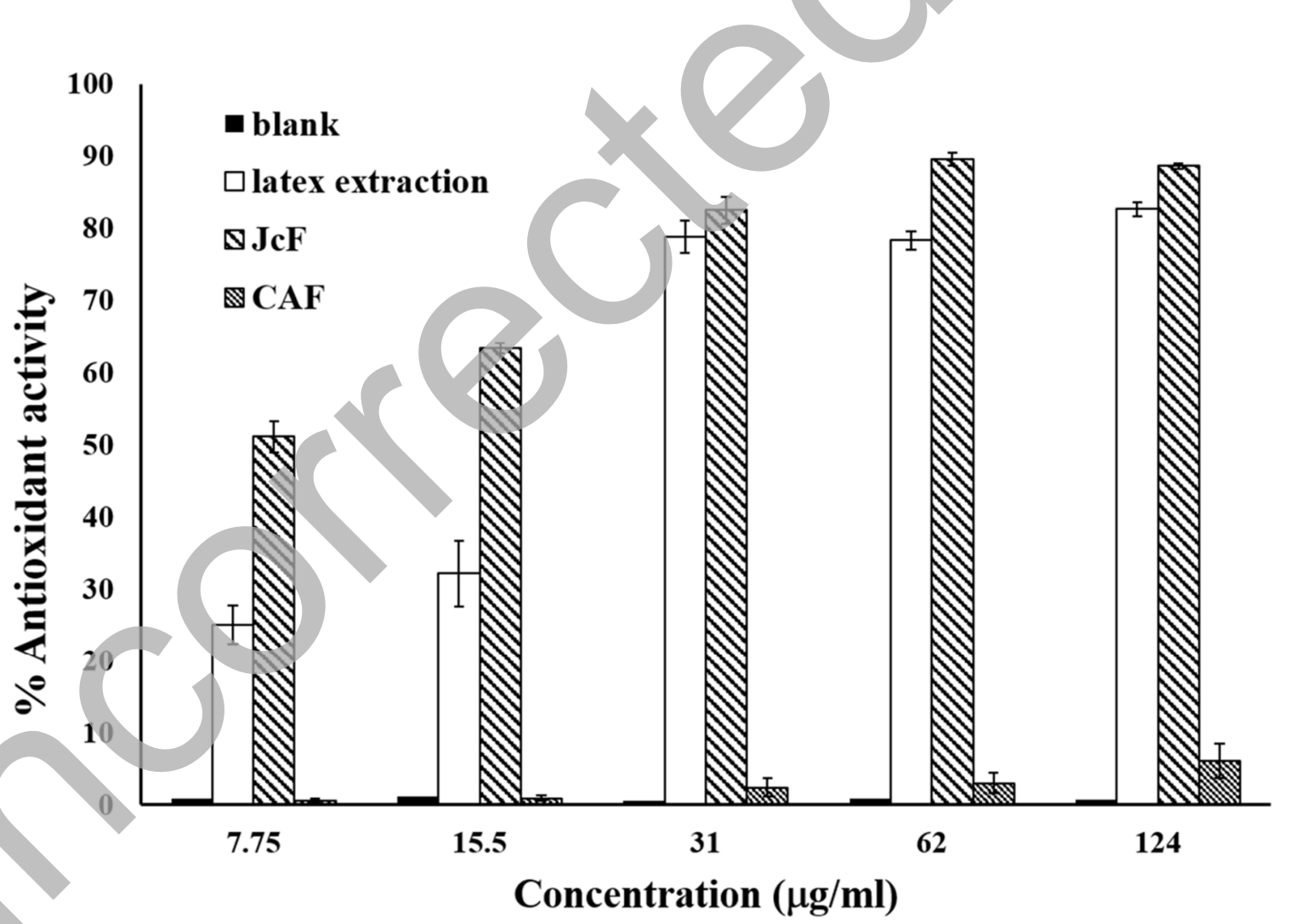

Figure 4 

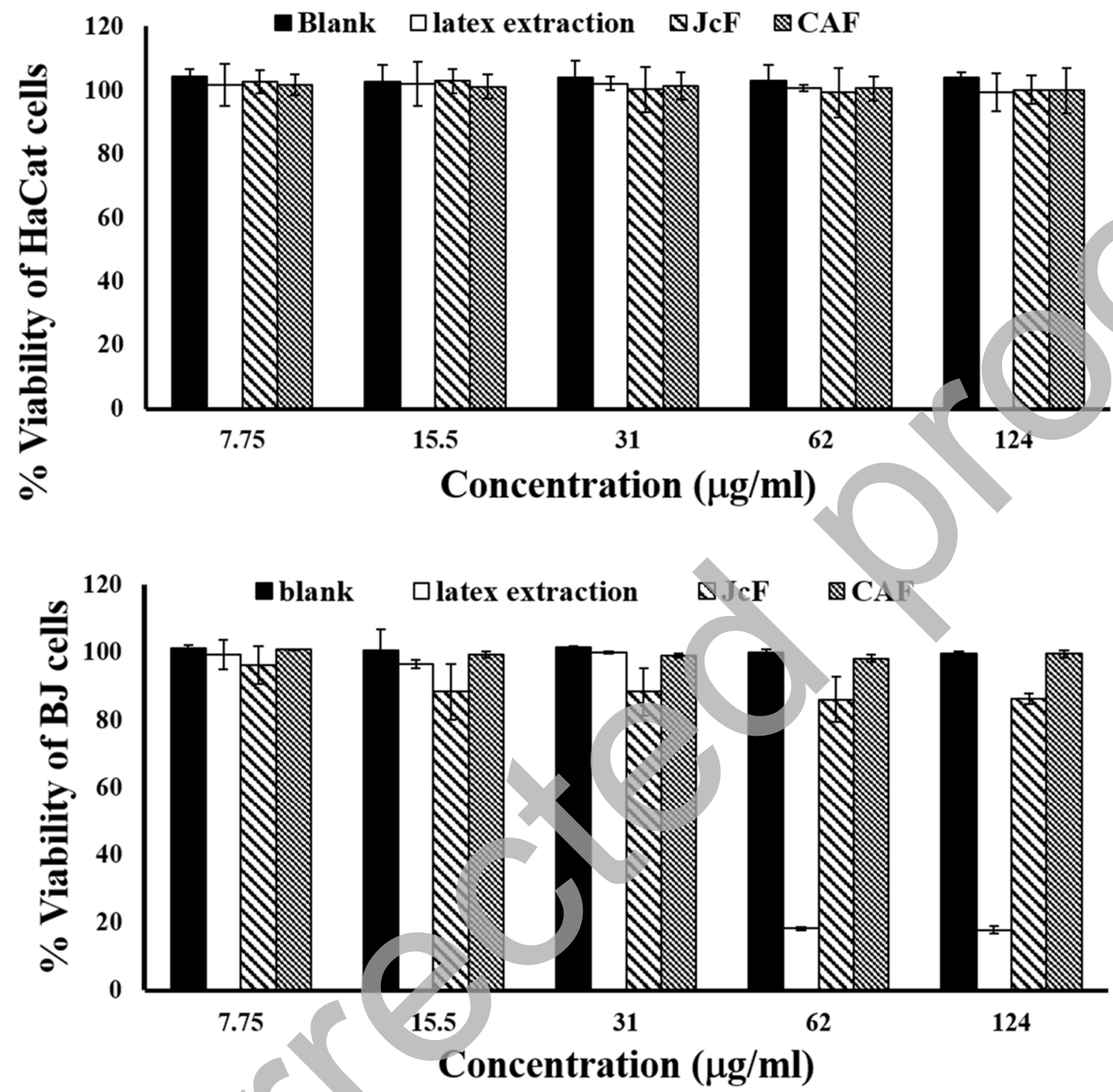

Figure 5 


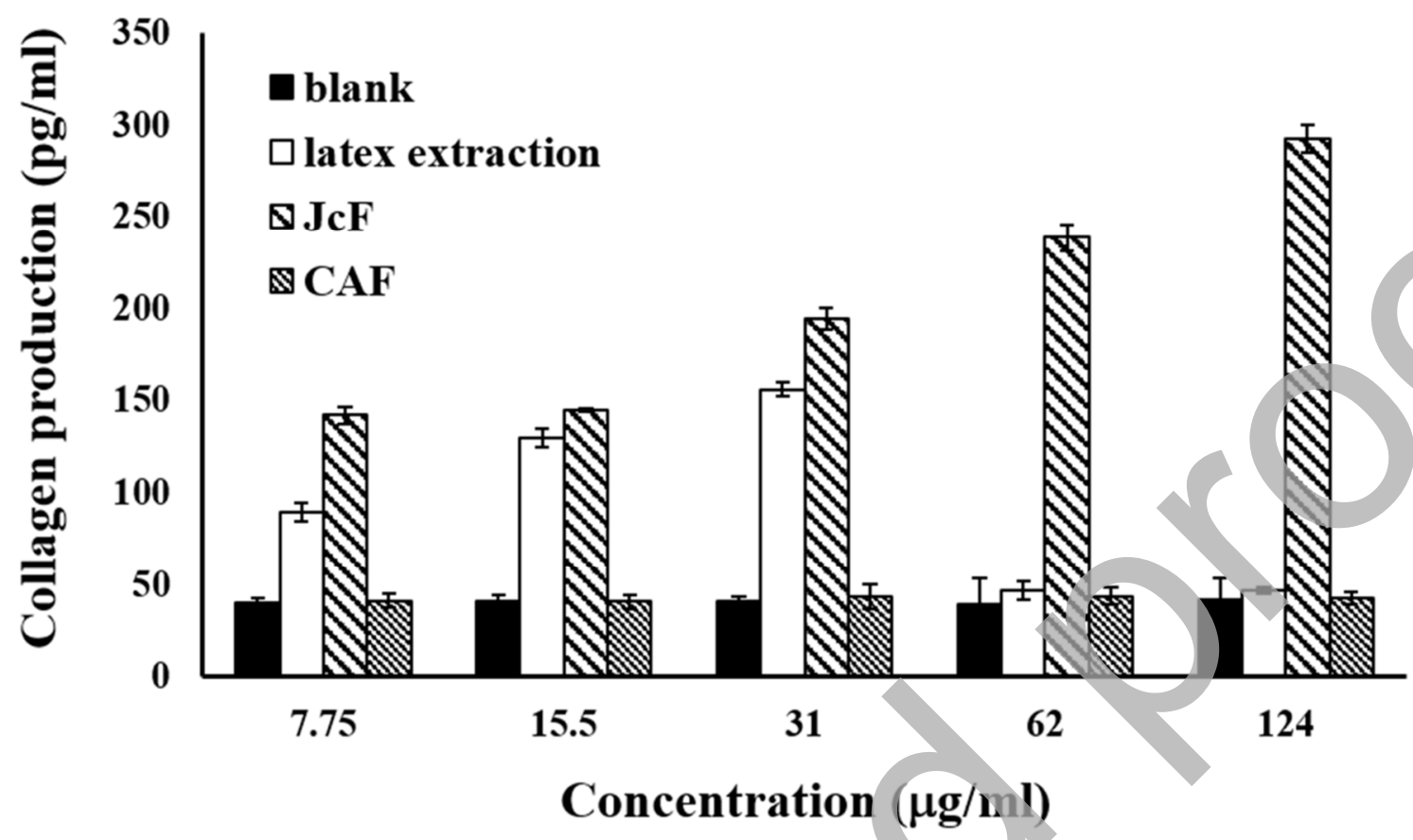

Figure 6 
A
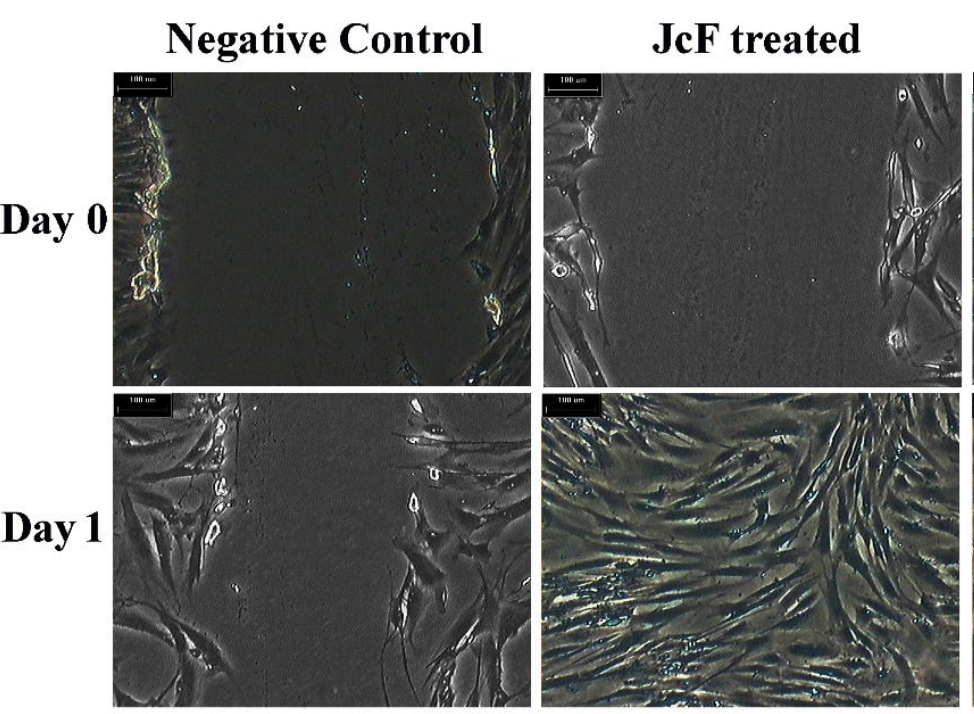

Proteoglycan-IPC

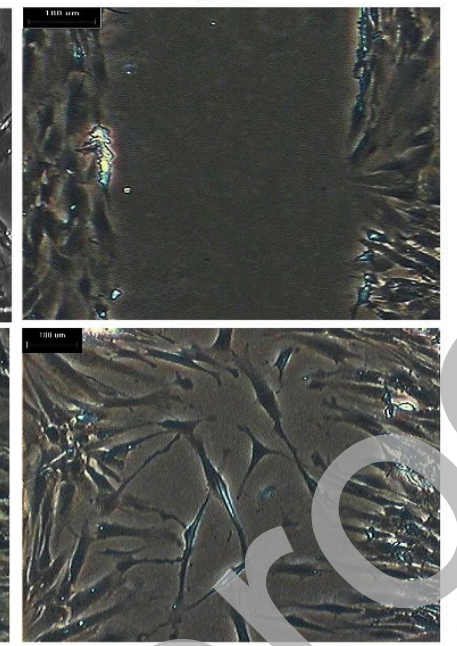

B

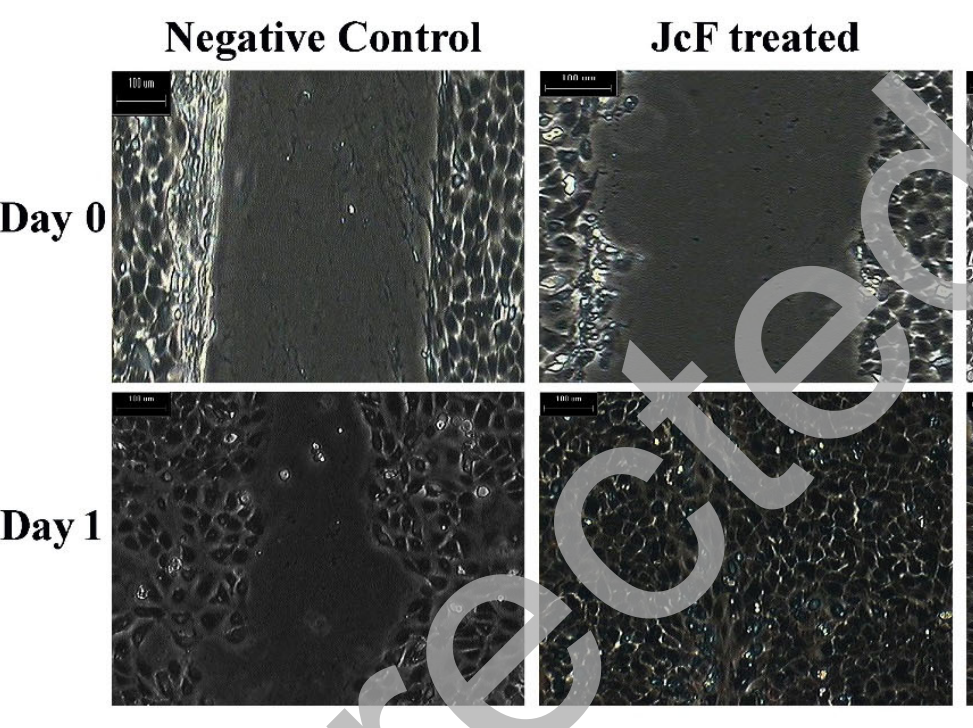

Proteoglycan-IPC

Figure 7 